\title{
An experimental studies on high seismic performance shear walls
}

\author{
[ WEN-I LIAO ]
}

\begin{abstract}
Past RC wall panel tests of reinforced concrete membrane elements under reversed cyclic loading have much greater ductility when steel bars are provided in the direction of principal tensile stress. In order to improve the ductility of shear walls under earthquake loading, high seismic performance shear walls have been proposed to have steel bars in the same direction as the principal direction of applied stresses in the critical regions of shear walls. This paper presents the test results of two shear walls under shake table excitation and two shear walls under reversed cyclic loading. In the specimens under shake table tests, steel bars were provided at angles of either 90 degrees or $\mathbf{4 5}$ degrees to the horizontal. In the reversed cyclic tests, one-half of the steel bars were placed at an angle of $\mathbf{4 5}$ degrees to the horizontal in the low-rise shear wall and at an angle of 65 degrees to the horizontal in the bottom portion of the mid-rise shear wall. Based on the experimental results, the tested shear walls with reinforcement oriented close to the principal tensile direction of applied stresses have greater ductility than that of the conventional shear wall.
\end{abstract}

Keywords-shear wall, reinforced concrete, ductility, cyclic loading, shake table

\section{Introduction}

Structural walls can be divided into three groups based on the ratio of height to length. When the height to length ratio is greater than 2.0, they are called high-rise structural walls; when the height to length ratio is less than 1.0, they are called low-rise structural walls; when the height to length ratio is between 1.0 and 2.0, they are called mid-rise structural walls. For high-rise shear walls, the failure is mainly governed by flexure. In contrast, for low-rise shear walls, the failure is mainly governed by shear. For mid-rise shear walls, the failure is governed by both flexure and shear. For the low-rise and mid-rise structural walls, which are dominated by shear, they are also called shear walls.

The stiffness characteristics and shear strength of shear walls was investigated during the 1990s [1-5]. In the past 20 years, attention was given to the seismic behavior of reinforced concrete shear walls. Strength, ductility characteristic and energy dissipation capacity of shear walls under earthquake loading have also been studied [7-8]. Test results show that conventional low-rise and mid-rise shear walls have less ductility and lower energy dissipation capacity, which can be observed as a "pinching effect" in the hysteretic response of shear walls.

Professor Wen-I Liao

National Taipei University of Technology

Taipei, Taiwan.
The reason why conventional low-rise shear walls do not exhibit satisfactory ductility is that there is an angle between the orientation of the rebars and the principal direction of the applied tensile stress. Therefore the ductility of the rebars can not be fully utilized.

Sittipunt et al. [9] conducted cyclic tests on high-rise structural walls with diagonal web reinforcement. Test results showed that high-rise structural walls with diagonal web reinforcement had better energy dissipation in the hysteresis loops compared to conventional structural walls with web reinforcement in the horizontal and vertical directions. Recent work by Mansour et al. [10] and Mansour [11] showed that the effect of the steel grid orientation played an important role on the cyclic shear stress - shear strain relationships of reinforced concrete panels. Both the energy dissipation capacity and ductility were greater when steel bars were oriented in the principal direction of the applied tensile stress.

In order to improve the seismic behavior of shear walls under earthquake loading, shear walls have been designed to have steel bars in the principal tensile direction of applied stresses in critical regions. This paper presents the results from the shake table tests on two low-rise shear walls and from the reversed cyclic loading tests on a low-rise and a mid-rise shear wall. It is found that the seismic performance of shear walls can be improved when steel bars are provided in the principal tensile direction of applied stresses.

\section{Test Program}

Two low-rise shear walls ( $\mathrm{SC}, \mathrm{SN}$ ) were tested on a shake table. The height to length of both walls was 0.5. SC and $\mathrm{SN}$ were designed with a scale factor of 1:4 based on the capacity limit of the shake table. Two shear walls (RL, RM) were tested under reversed cyclic horizontal loading. The height to length ratio of the wall RL was 0.5 . The height to length ratio of the wall RM was 1.5. The scale factor of specimens RL and RM was 1:2. The steel ratio of all four specimens was $0.48 \%$, which satisfied the minimum wall reinforcement required by the ACI code.

\section{A. Shake Table Test}

Two low-rise shear walls (SC, SN) were tested on a shake table. The height to length ratio of both walls was 0.5 . The height, length, and thickness of the two shear walls were $0.7 \mathrm{~m}, 1.4 \mathrm{~m}$ and $0.06 \mathrm{~m}$, respectively. The first character of the specimen names, $\mathrm{S}$, stands for the shake table tests. In specimen SC, C stands for a conventional wall. Steel bars were provided in the horizontal and vertical directions. In specimen $\mathrm{SN}, \mathrm{N}$ stands for a next generation wall, i.e. steel bars were provided at an angle of 45 degrees to the horizontal, which was approximately equal to the 
Proc. of Eighth International Conference On Advances in Civil, Structural and Mechanical Engineering - ACSM 2018

Copyright (C) Institute of Research Engineers and Doctors, USA. All rights reserved.

ISBN: 978-1-63248-154-2 doi: 10.15224/978-1-63248-154-2-09

orientation of the principal direction of applied tensile stress based on the results from a finite element analysis.
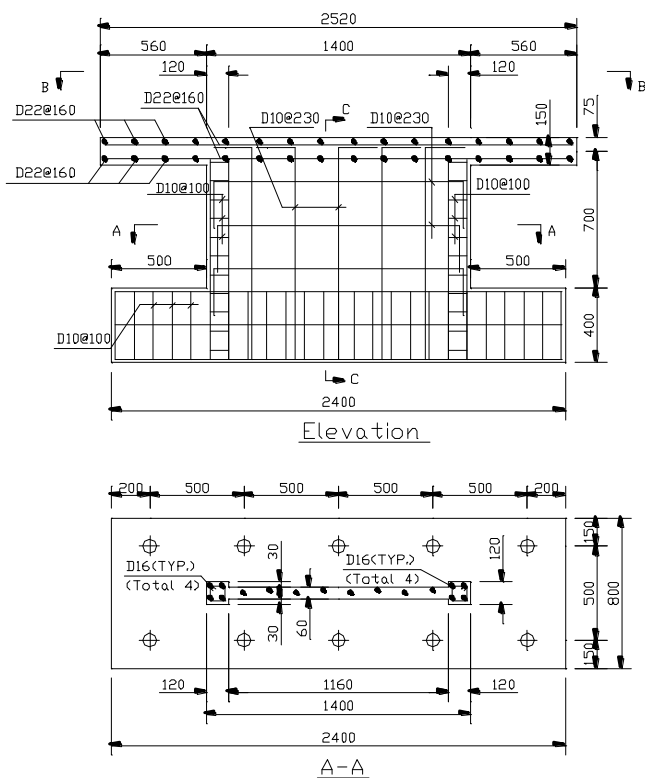

(a) $\mathrm{SC}$
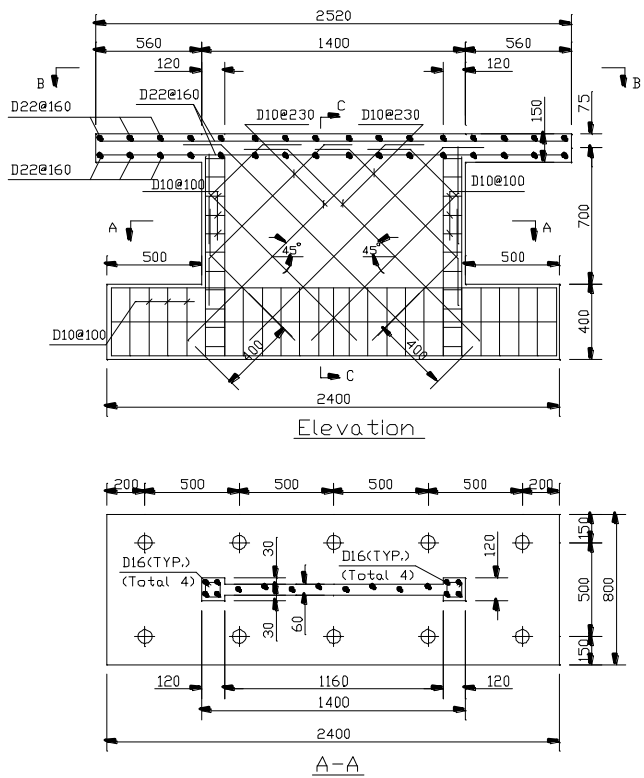

(b) $\mathrm{SN}$

Figure 1. Dimensions and reinforcement of specimens SC and SN (unit: $\mathrm{mm}$ )

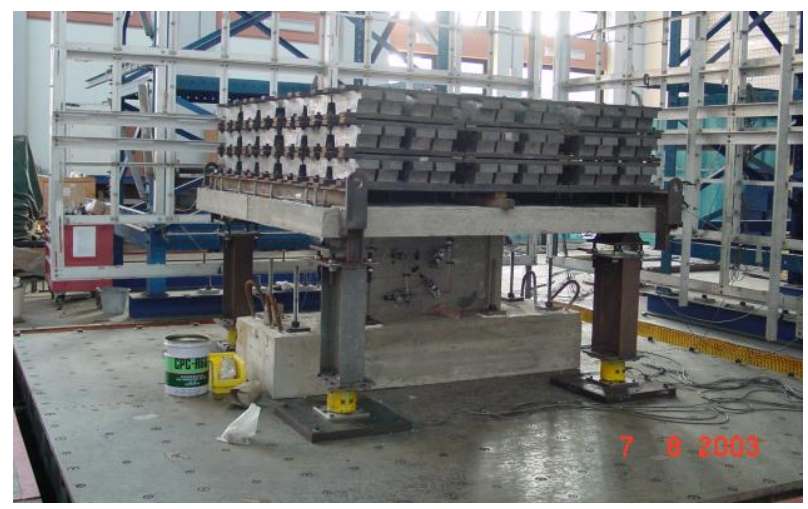

Figure 2. Test set-up of shake table tests
TABLE I. TEST RUNS OF SPECIMEN SC

\begin{tabular}{|c|c|c|}
\hline Run number & $\begin{array}{c}\text { PGA } \\
\text { (peak ground acceleration) }\end{array}$ & Remark \\
\hline 1 & $0.05 \mathrm{~g}^{*}$ & \\
\hline 2 & $0.4 \mathrm{~g}^{*}$ & Steel yielded \\
\hline 3 & $0.8 \mathrm{~g} *$ & \\
\hline 4 & $1.2 \mathrm{~g}^{*}$ & Failure \\
\hline 5 & $1.6 \mathrm{~g}^{*}$ & $2.0 \mathrm{~g} *$ \\
\hline 6 & \multicolumn{3}{|c|}{ Note: $*$ Mass $=13500 \mathrm{~kg}$} \\
\hline
\end{tabular}

TABLE II. TEST RUNS OF SPECIMEN SN

\begin{tabular}{|c|c|c|}
\hline Run number & $\begin{array}{c}\text { PGA } \\
\text { (peak ground acceleration) }\end{array}$ & Remark \\
\hline 1 & $0.05 \mathrm{~g}^{*}$ & \\
\hline 2 & $0.4 \mathrm{~g} *$ & Steel yielded \\
\hline 3 & $0.8 \mathrm{~g} *$ & \\
\hline 4 & $1.2 \mathrm{~g} *$ & \\
\hline 5 & $1.6 \mathrm{~g} *$ & Failure \\
\hline 6 & $1.8 \mathrm{~g} * *$ & $\mathrm{~g} * *$ \\
\hline 7 & $2.0 \mathrm{~g} *$ & $\mathrm{~kg} ; *$ Mass $=16000 \mathrm{~kg}$ \\
\hline
\end{tabular}

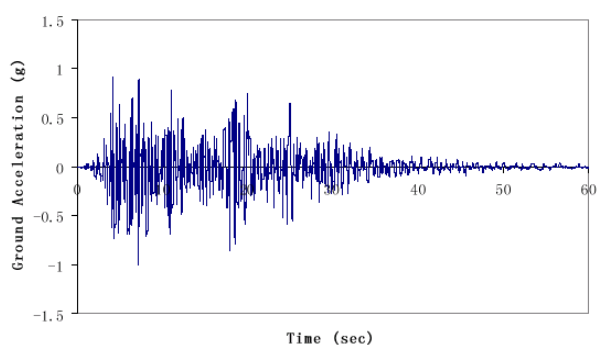

Figure 3. Normalized TCU078 seismogram of the 1999 Taiwan earthquake

The concrete compressive strength of the shear walls and foundations was 34.0 MPa. As shown in Fig. 1, No.3 bars were used as the steel grids of the two walls and the stirrups at the bottom of the foundations of the two walls. No.5 bars were used as the longitudinal bars at the boundary elements of the two walls. No.7 bars were used in the top plate and the bottom foundations. The yield stress of the No.3 bars and No.5 bars was $346 \mathrm{MPa}$ and $403 \mathrm{MPa}$, respectively. The ultimate stress of the No.3 bars and No.5 bars was $474 \mathrm{MPa}$ and $566 \mathrm{MPa}$, respectively.

Each of the end regions of the shear wall was provided with a column as a boundary element. The cross section of the columns were $120 \mathrm{~mm}$ by $120 \mathrm{~mm}$ and provided with longitudinal bars and stirrups. One layer of No.3 bars at 230 $\mathrm{mm}$ spacing in both perpendicular directions were used for both specimens. The steel ratios in the perpendicular directions for both specimens were $0.48 \%$. The anchorage length of the diagonal rebars in the wall and longitudinal rebars in the boundary elements into the foundation was determined by the development length procedure given in the ACI code.

The horizontal displacements and response acceleration of the walls were measured by LVDTs and accelerometers, respectively. Fig. 2 shows the test set-up of the shake table tests. For specimen SC, a total mass of $13500 \mathrm{~kg}$ was put on the top plate. For specimen $\mathrm{SN}$, a total mass of $13500 \mathrm{~kg}$ was placed on the top plate in the first five test runs. Because no obvious failure was observed after 5 test runs, an additional mass of $2500 \mathrm{~kg}$ was added to the plate for the last two runs. 
Proc. of Eighth International Conference On Advances in Civil, Structural and Mechanical Engineering - ACSM 2018

Copyright (C) Institute of Research Engineers and Doctors, USA. All rights reserved.

ISBN: 978-1-63248-154-2 doi: 10.15224/978-1-63248-154-2-09

The TCU078Eji seismogram of the 1999 Taiwan earthquake was used as the ground motion acceleration. The normalized seismogram is shown in Fig. 3. A summary of the test runs is included in Table 2 and Table 3 for specimens SC and SN, respectively.

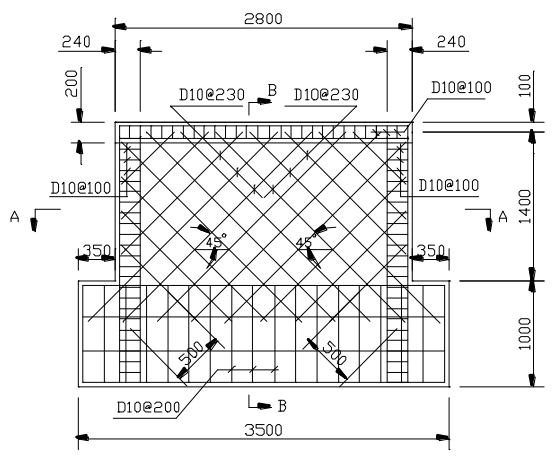

Elevation
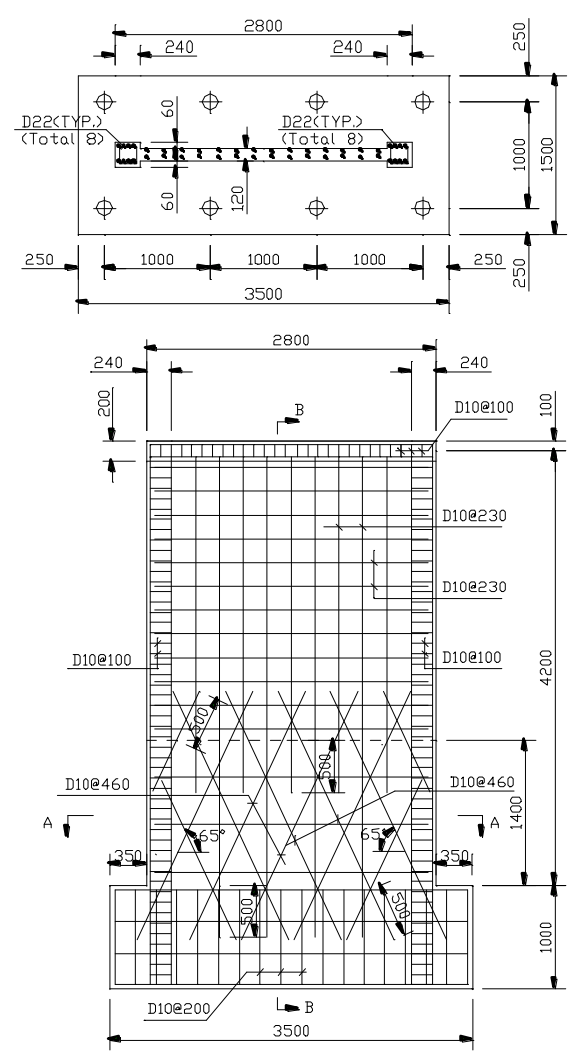

Elevation

Figure 4. Dimensions and reinforcement of specimens RL and RM (Dimension: $\mathrm{mm}$ )

\section{B. Reversed Cyclic Tests}

Two shear walls (RL, RM) were tested under reversed cyclic horizontal loading. The height to length ratio of the wall RL was 0.5 . The first character of the specimen names, $\mathrm{R}$, stands for reversed cyclic tests. The second character, $\mathrm{L}$ or $\mathrm{M}$, represents low-rise or mid-rise wall. The height, length, and thickness of wall RL were $1.4 \mathrm{~m}, 2.8 \mathrm{~m}$ and 0.12 $\mathrm{m}$, respectively. The height to length ratio of the wall RM was 1.5 . The height, length, and thickness of wall RM were $4.2 \mathrm{~m}, 2.8 \mathrm{~m}$ and $0.12 \mathrm{~m}$, respectively. The steel ratio for both specimens was $0.48 \%$.In the wall of specimen RL, two layers of No.3 bars at $230 \mathrm{~mm}$ spacing were used. The orientation of the steel bars was at an angle of 45 degrees to the horizontal, which was approximately equal to the orientation of the principal direction of applied tensile stress based on the results from a finite element analysis.

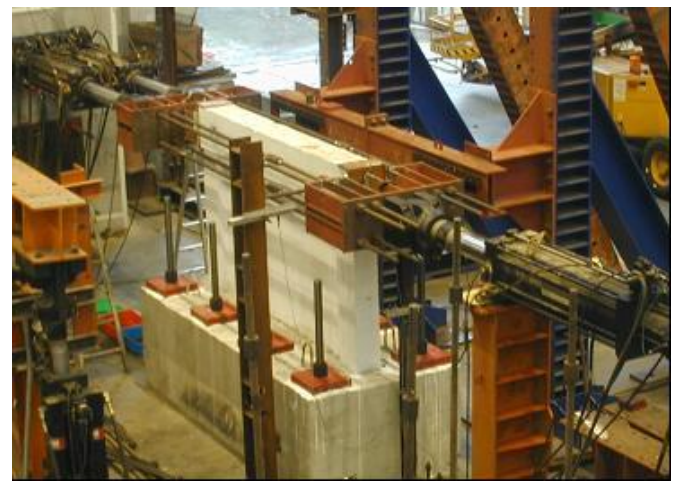

Figure 5. Set-up of reversed cyclic tests

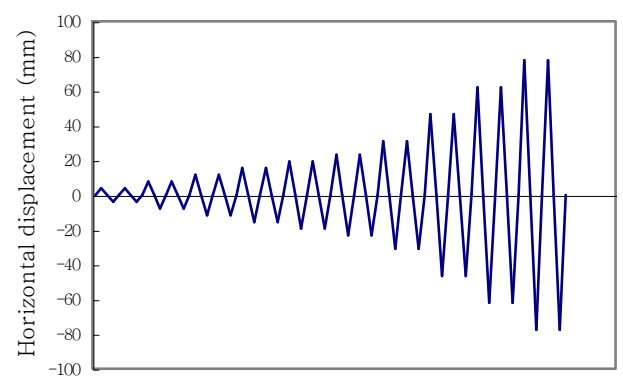

Figure 6. Displacement control scheme of reversed cyclic tests

According to the analytical analysis, the orientation of the principal direction of tensile stress was at an angle of 65 degrees to the horizontal in the bottom part of wall RM, which is the critical region of the wall under reversed cyclic loading. In the top part of wall RM, two layers of No.3 bars at $230 \mathrm{~mm}$ spacing in horizontal and vertical directions were provided. In the bottom part of wall RM, two layers of No.3 bars at $460 \mathrm{~mm}$ spacing in the horizontal and vertical directions were used and another two layers of No.3 steel bars spaced at $460 \mathrm{~mm}$ at an angle of 65 degrees to the horizontal were used.

The concrete compressive strength of both specimens was 36.0 MPa. As shown in Fig. 4, No.3 bars were used as the steel grids of the walls and the stirrups of the boundary elements and bottom foundations. No.7 bars were used as the longitudinal bars of the boundary elements. The yield stress of the No.3 bars and No.7 bars was $329 \mathrm{MPa}$ and 545 $\mathrm{MPa}$, respectively. The ultimate stress of the No.3 bars and No.7 bars was $485 \mathrm{MPa}$ and $705 \mathrm{MPa}$, respectively.

The dimensions and reinforcement of specimens RL and RM are shown in Fig. 4. Each of the end regions of the shear walls was provided with a boundary element. The cross sections of the boundary elements were $240 \mathrm{~mm}$ by $240 \mathrm{~mm}$ and were provided with longitudinal bars and stirrups. The anchorage length of the diagonal rebars in the wall and longitudinal rebars in the boundary elements into the foundation was determined by the development length procedure given in the ACI code.

Fig. 5 shows the test set-up for the reversed cyclic tests. Reversed cyclic horizontal loads were applied at the top of the shear wall. The test procedure was controlled by the horizontal displacement at the top of the wall. The scheme of the displacement control is shown in Fig. 6. At each 
Proc. of Eighth International Conference On Advances in Civil, Structural and Mechanical Engineering - ACSM 2018

Copyright (C) Institute of Research Engineers and Doctors, USA. All rights reserved.

ISBN: 978-1-63248-154-2 doi: 10.15224/978-1-63248-154-2-09

displacement control point, two reversed cycles were repeated.

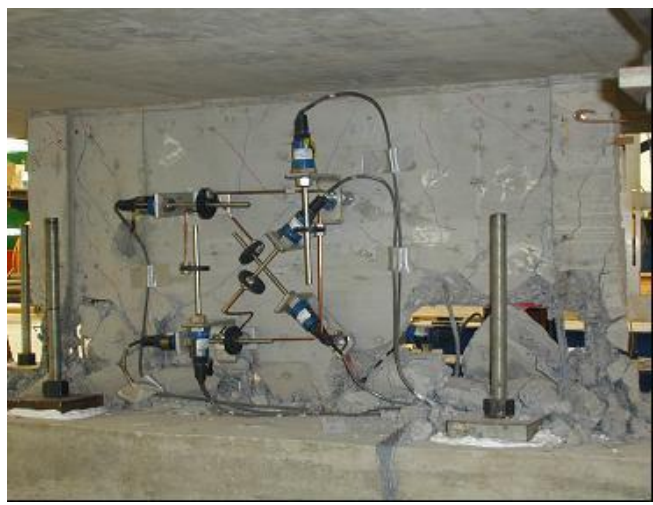

Figure 7(a). Photo of the specimen SC in failure stage (taken at the sixth run $P G A=2.0 \mathrm{~g}$ )

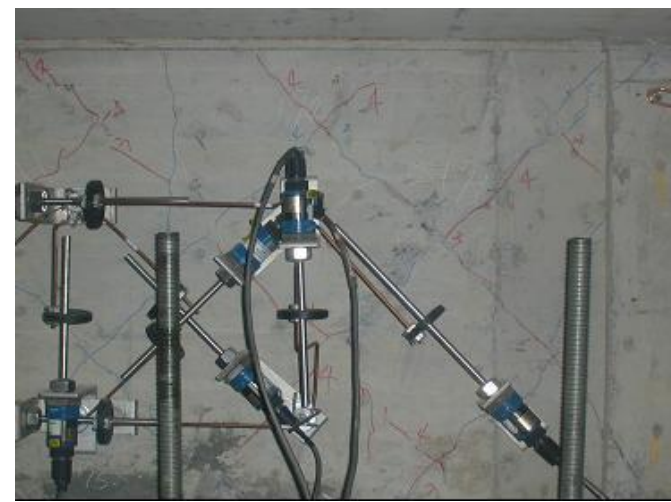

Figure 7(b). Photo of the specimen SN (taken at the seventh run $\mathrm{PGA}=2.0 \mathrm{~g})$

\section{Experimental Results}

\section{A. Shake Table Tests}

For specimen SC, the first yield of steel bars occurred at the third run when the maximum ground acceleration equaled $0.8 \mathrm{~g}$. Failure of the wall happened at the sixth run when the maximum ground acceleration equaled $2.0 \mathrm{~g}$. At failure, concrete crushing, spalling, and buckling of the reinforcement was observed. A photo taken at the final failure stage of specimen $\mathrm{SC}$ is shown in Fig. 7(a). The response of the selected test run is shown in Fig. 8. By comparing the responses of each test runs, it is shown that the maximum displacement and acceleration in each run increased progressively when the peak ground acceleration (PGA) of the input seismogram increased.

For specimen $\mathrm{SN}$, the first yield of the steel bars occurred at the third run when the maximum ground acceleration equaled $0.8 \mathrm{~g}$. After the fifth run, it was thought that additional mass was needed to make the wall collapse, and hence a mass of $2500 \mathrm{~kg}$ was added to the top plate. Another two runs (sixth and seventh runs) were performed. A photo taken at the last run is shown in Fig. 7(b). Different from specimen SC, cracks in the concrete of wall SN were developed uniformly at 45 degree angles and spalling of the concrete was observed. Shear wall SN did not exhibit an obvious failure at the end of the tests due to the restraint of the shake table capacity. The response of selected test run of specimen $\mathrm{SN}$ are shown in Fig. 9.

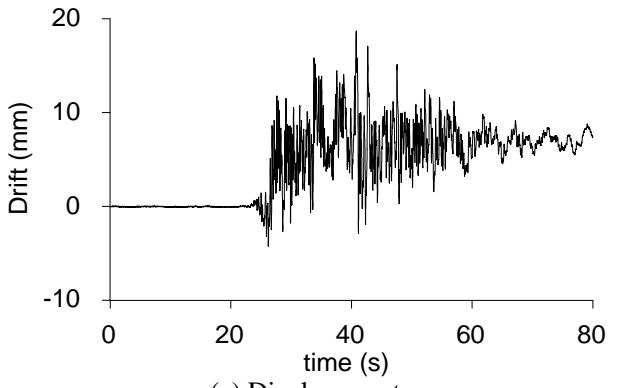

(a) Displacement

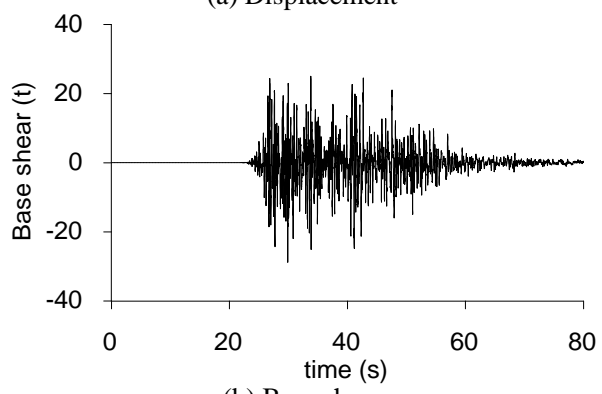
$6 \mathrm{~g}$

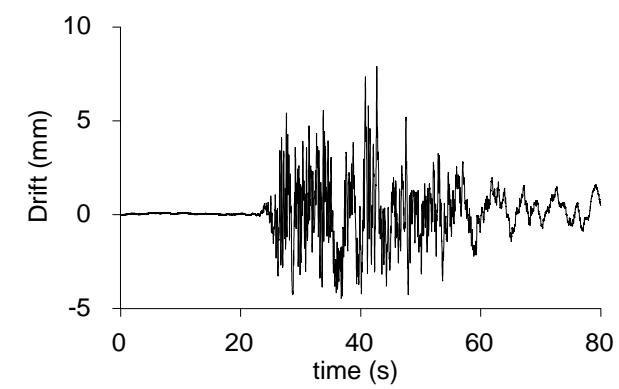

(a) Displacement

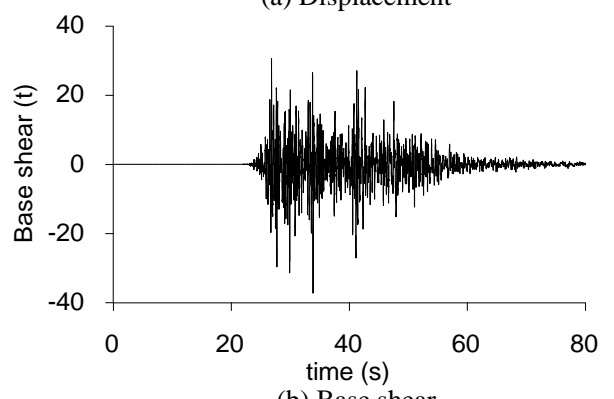

(b) Base shear

Figure 9. Response of specimen $\mathrm{SN}$ at the sixth test run $\mathrm{PGA}=1.6 \mathrm{~g}$

TABLE III. DUCTILITY AND MAXIMUM SHEAR FORCE OF SC AND SN

\begin{tabular}{|c|c|c|c|c|c|}
\hline & $\begin{array}{c}\Delta_{\mathrm{y}} \\
(\mathrm{mm})\end{array}$ & $\begin{array}{c}\Delta_{\mathrm{m}} \\
(\mathrm{mm})\end{array}$ & $\begin{array}{c}\Delta_{\mathrm{u}} \\
(\mathrm{mm})\end{array}$ & $\begin{array}{c}\text { Ductility } \\
\mu\end{array}$ & $\begin{array}{c}\text { Maximum } \\
\text { shear force } \\
(\mathrm{KN})\end{array}$ \\
\hline $\mathrm{SC}$ & 1.90 & 7.35 & 10.7 & 5.6 & 284.7 \\
\hline $\mathrm{SN}$ & 1.35 & 3.87 & 11.3 & 8.4 & 311.0 \\
\hline
\end{tabular}

The ductility and maximum shear force of specimens SC and SN are shown in Table 3. Test results show that the ductility of specimen SN is larger than specimen SC. The yield displacement of $\mathrm{SN}$ is $40 \%$ less than that of SC, which shows that the steel orientation has a big effect on the yield behavior of shear walls. It should be noted that both the ductility and maximum shear force for specimen SN could have been determined to be higher if the shake table had a greater capacity. 
Proc. of Eighth International Conference On Advances in Civil, Structural and Mechanical Engineering - ACSM 2018

Copyright (C) Institute of Research Engineers and Doctors, USA. All rights reserved.

ISBN: 978-1-63248-154-2 doi: 10.15224/978-1-63248-154-2-09

\section{B. Reversed Cyclic Tests}

Figure 10 shows the cracking pattern and failure mode of specimen RL. The cracking of the concrete was drawn on the white painted faces of the specimen during the tests. Uniformly distributed cracks were observed and the crack orientations under reversed cyclic loading were nearly perpendicular and close to 45 degrees to the horizontal. No failure at the boundary ends of the wall was found in specimen RL. Rebar buckling and concrete crushing around the compression bars were observed at the middle region and the top corner of the wall when the specimen failed. The cracking pattern and failure mode of specimen RM is shown in Fig. 11. The cracks in the concrete at the bottom part of the wall are close to 65 degrees, which is close to the principal stress direction of the wall and the designed steel grid orientations. The boundary did not fail during the tests. Concrete crushing and rebar buckling at the bottom of the wall were observed in the final stage of the tests.

The force-displacement relationships of specimens RL and RM are shown in Fig. 12 and Fig. 13, respectively. No obvious pinching effect was observed from the hysteretic loops of specimen RL. A pinching effect can be found in the last force-displacement hysteretic loops of specimen RM because the specimen had already failed. Ductility and strength--The ductility and maximum shear force of specimens RL and RM are shown in Table 4. It can be seen from Table 4 that the ductility of specimen RL (8.7) is about the same as that of specimen SN, and the ductility of specimen RM is greater than that of specimen RL.

The ductility of specimens RL and RM will be improved if the rebar buckling can be prevented. If transverse reinforcement were to be used to wrap the diagonal rebars they would be strengthened in compression [12] which may prevent the rebars from buckling and delay crushing of the concrete.

TABLE IV. DUCTILITY AND MAXIMUM SHEAR FORCE OF RL AND RM

\begin{tabular}{|c|c|c|c|c|c|}
\hline & $\begin{array}{c}\Delta_{\mathrm{y}} \\
(\mathrm{mm})\end{array}$ & $\begin{array}{c}\Delta_{\mathrm{m}} \\
(\mathrm{mm})\end{array}$ & $\begin{array}{c}\Delta_{\mathrm{u}} \\
(\mathrm{mm})\end{array}$ & $\begin{array}{c}\text { Ductility } \\
\mu\end{array}$ & $\begin{array}{c}\text { Maximum } \\
\text { shear force } \\
(\mathrm{KN})\end{array}$ \\
\hline RL & 1.7 & 10.13 & 14.78 & 8.7 & 2313.1 \\
\hline RM & 8.6 & 78.55 & 86.09 & 10.0 & 1102.7 \\
\hline
\end{tabular}

\section{CONCLUSIONS}

(1) The tested shear walls with steel grid orientation close to the principal tensile direction of applied stress have greater ductility than that of conventional shear walls.

(2) For low-rise shear walls with steel grid orientations of 45 degrees to the horizontal, both the shake table tests and reversed cyclic tests give about the same ductility.

(3) Because of rebar buckling, shear walls with steel grid orientations close to the principal tensile direction of applied stress did not provide much greater ductility than that of conventional walls. To improve the seismic performance of reinforced concrete shear walls both steel grid orientation and rebar buckling prevention need to be taken into account.

\section{Acknowledgment}

The authors gratefully acknowledge the financial support granted by the Ministry of Science and Technology, R.O.C.
The facilities for research provided by National Center for Research on Earthquake Engineering are also highly appreciated.

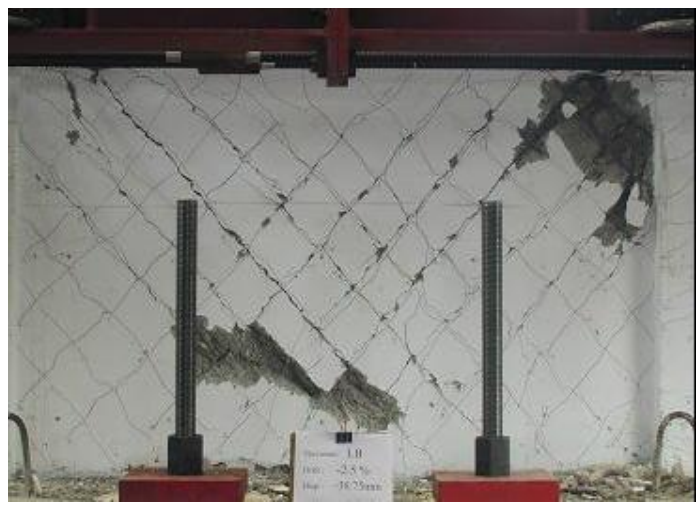

Figure 10. Cracking pattern at $2.5 \%$ drift and failure mode of specimen RL

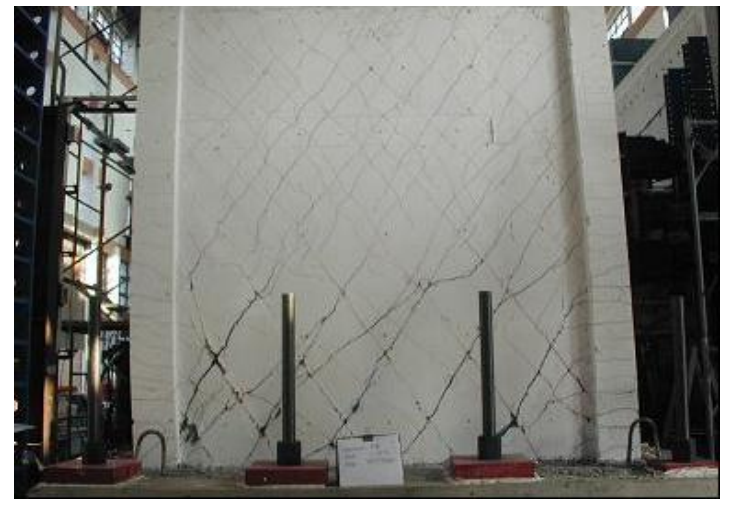

Figure 11. Cracking pattern at $1.5 \%$ drift and failure mode of Specimen RM

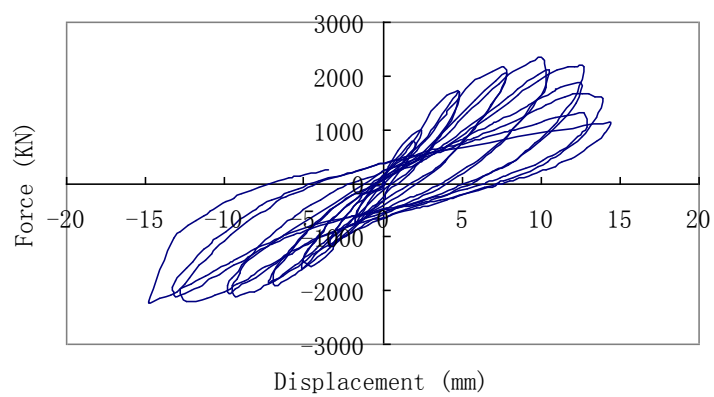

Figure 12. Force-displacement of specimen RL

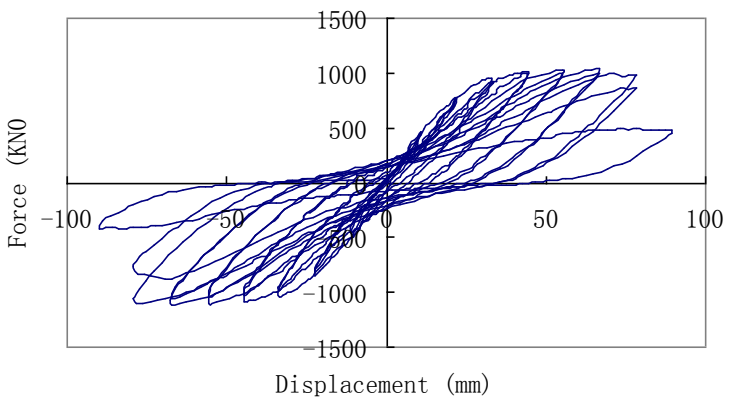

Figure 13. Force-displacement of specimen RM 
Proc. of Eighth International Conference On Advances in Civil, Structural and Mechanical Engineering - ACSM 2018

Copyright (C) Institute of Research Engineers and Doctors, USA. All rights reserved.

ISBN: 978-1-63248-154-2 doi: 10.15224/978-1-63248-154-2-09

\section{References}

[1] Elnashai, A. S., Pilakoutas, K. and Ambraseys, N. N. "Experimental behaviour of reinforced concrete walls under earthquake loading," Earthquake Engineering \& Structural Dynamics, Vol. 19, No. 3, Apr, 389-407, 1990.

[2] Farrar, C. R. and Baker, W. E. "Measuring the stiffness of concrete shear walls during dynamic tests," Experimental Mechanics, Vol. 32, No. 2, 179-183, 1992.

[3] Cheng, F. Y., Mertz, G. E., Sheu, M. S. and Ger, J. F. "Computed versus observed inelastic seismic low-rise RC shear walls," Journal of Structural Engineering, Vol. 119, No. 11, Nov, 3255-3275, 1993.

[4] Colotti, V. "Shear behavior of RC structural walls," Journal of Structural Engineering, Vol. 119, No. 3, Mar, 728-746, 1993.

[5] Eberhard, M. O. and Sozen, M.A. (1993). "Behavior-based method to determine design shear in earthquake-resistant walls," Journal of Structural Engineering, Vol. 119, No. 2, Feb, 619-640.

[6] Pilakoutas, K. and Elnashai, A. S. "Cyclic behavior of reinforced concrete cantilever walls, Part II: discussions and theoretical comparisons," ACI Structural Journal, Vol. 92, No. 4, Jul-Aug, 425434, 1995.

[7] Mo, Y. L. and Lee, Y. C. "Shake table tests on small-scale low-rise structural walls with various sections," Magazine of Concrete Research, Vol. 52, No. 3, Jun., 177-184, 2000.

[8] Tasnimi, A. A. "Strength and deformation of mid-rise shear walls under load reversal," Engineering Structures, Vol. 22, No. 4, Apr, 311-322, 2000.

[9] Sittipunt, C., Wood, S. L., Lukkunaprasit, P. and Pattararattanakul, P. "Cyclic behavior of reinforced concrete structural walls with diagonal web reinforcement." ACI Structural Journal, Vol. 98, No. 4, July/August, 554-562, 2001.

[10] Mansour, M., Lee, J. Y. and Hsu, T. T. C. "Constitutive Laws of Concrete and Steel Bars in Membrane Elements under Cyclic Loading," Journal of Structural Engineering, ASCE, Vol. 127, No. 12 , Dec., 1402-1411, 2001.

[11] Mansour, M. "Behavior of Reinforced Concrete Membrane Elements under Cyclic Shear: Experiments to Theory," $\mathrm{PhD}$ dissertation, Department of Civil Engineering, University of Houston, August, 2001.

[12] Park, P. and Paulay, T. Reinforced Concrete Structures. John Wiley \& Sons, Inc, 1975.

[13] Lopes, M. S. (2001). "Experimental shear-dominated response of RC walls. Part I: Objectives, methodology and results," Engineering Structures, Vol. 23, No. 3, Mar, 229-239.

About Author (s):

Dr. Wen-I Liao is a Professor at
Department of Civil Engineering, National
Taipei University of Technology. He
received his Ph. D degree at 1997 from
National Taiwan University. His research
interesting is structural health monitoring,
ground motion simulation and
experimental structural mechanics.

